LEMBAR KERJA MULTIPLEXING

Disusun Oleh :

Citra Kurniawan

Sekolah Tinggi Teknik Malang

airakurniawan@gmail.com

\title{
Perhitungan Metode Chip Spreading Code 8 bit pada Code Division Multiplexing (CDM)
}

- $\quad$ Pengalokasian kode unik (8-chip spreading code) bagi 5 pengguna

$\begin{array}{lll}\text { - } & \text { kode untuk A : } & 10111101 \\ \text { - } & \text { kode untuk B : } & 01100110 \\ \text { - } & \text { kode untuk C : } & 11001001 \\ \text { - } & \text { kode untuk D : } & 11001010 \\ \text { - } & \text { kode untuk E : } & 00101011\end{array}$

Misalkan pengguna A mengirim bit 1, pengguna B mengirim bit, pengguna $C$ mengirim bit 1 , pengguna $\mathrm{D}$ mengirim bit 1 dan pengguna $\mathrm{E}$ mengirimkan bit 0 Maka pada saluran transmisi akan dikirimkan kode berikut :
A mengirim bit $1 \rightarrow$
$\mathrm{B}$ mengirim bit $0 \rightarrow$
C mengirim bit $1 \rightarrow$
D mengirim bit $1 \rightarrow$
E mengirim bit $1 \rightarrow$
Hasil penjumlahan:

\begin{tabular}{|c|c|c|c|c|c|c|c|}
\hline $10111101 \rightarrow$ & + & - & + & + & + & + & $-\quad+$ \\
\hline $01100110 \rightarrow$ & + & - & - & + & + & - & $-\quad+$ \\
\hline $11001001 \rightarrow$ & + & + & - & - & + & - & $-\quad+$ \\
\hline $11001010 \rightarrow$ & + & + & - & - & + & - & +- \\
\hline $00101011 \rightarrow$ & - & - & + & - & + & - & ++ \\
\hline
\end{tabular}

Berapa interpretasi kode yang diterima B dan D :

- Pasangan dari B akan menginterpretasi kode yang diterima dengan cara :

$\left.\begin{array}{lllllllllll}\text { Sinyal yang diterima } & : & & +3 & -1 & -1 & -1 & +5 & -3 & -1 & +3 \\ \text { Kode B } & : & -1 & +1 & +1 & -1 & -1 & +1 & +1 & -1\end{array}\right]$ X

Nilai -16 akan diinterpretasi sebagai bit ' 0 ' karena mendekati nilai -8

- Pasangan dari $\mathrm{D}$ akan menginterpretasi kode yang diterima dengan cara :
Sinyal yang diterima

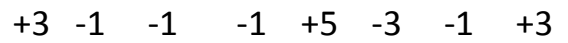
Kode A
Hasil perkalian (product)
\begin{tabular}{llllllll}
+1 & -1 & +1 & +1 & +1 & +1 & -1 & +1 \\
\hline+3 & +1 & -1 & -1 & +5 & -3 & +1 & +3
\end{tabular}$\times$
$+8$

Nilai +8 akan diinterpretasi sebagai bit ' 1 ' karena mendekati nilai +8 